\title{
Development of Guided Inquiry-Based Learning Materials in Acid-Base Topic, Enriched with Augmented Reality
}

\author{
Nuchrurita Rosida ${ }^{1}$, Munzil $^{2 *}$, M. Muchson ${ }^{2}$ \\ ${ }^{1}$ Chemistry Education Program, State University of Malang \\ ${ }^{2}$ Department of Chemistry, Faculty of Mathematics and Natural Sciences, State University of Malang \\ *Corresponding author. Email: munzil.fmipa@um.ac.id
}

\begin{abstract}
Implementation of guided inquiry learning models can be helped by the use of learning materials. Learning materials that have been using today are less interactive and pay little attention to the interaction of three chemical representations, especially acid-base material. The alternative that can be used is using digital learning media that can visualize three representations, especially submicroscopic, for example, augmented reality technology. The learning materials were developed using Lee and Owens development models which consisted of five stages. However, in this study, the stages carried out were only analyzing, designing, and developing. The developed learning materials then were validated by one chemistry lecturer and one chemistry teacher. The results are $86.7 \%$ for the overall content, and $82.7 \%$ on media aspect. For the readability test, the learning materials developed obtained an average of $92.17 \%$ which was very valid. Therefore, based on these results this learning materials can be used in the learning process of chemistry, especially in the acid-base material.

Keywords: acid-base, augmented reality, guided inquiry, learning materials
\end{abstract}

\section{INTRODUCTION}

Chemistry is one branch of science that has 3 roles, namely as a product of knowledge, process, and also attitude. To be able to integrate these three components, a learning model is needed. One learning model that can be used is inquiry. Inquiry-based learning can develop knowledge, thinking and reasoning skills, science process skills and scientific attitudes of students. Based on the teacher's involvement in the learning process, the inquiry learning model is divided into three, one of which is guided inquiry. Guided inquiry can be applied to classes where the learning process is rarely or even never used inquiry learning before. In this guided inquiry the teacher gives broad direction or guidance at the beginning of learning, then students learn to formulate their findings independently. This learning supports students to apply their knowledge, understand real-world situations, and develop students' scientific process skills and scientific attitudes. To be able to implement student learning independently, we need a supportive learning material.

Learning materials used in the learning process today can only emphasize chemistry in macroscopic and symbolic representations. Whereas sub-microscopic representation is less associated. This has triggered learning difficulties experienced by students. One of chemistry material that is still considered difficult is acid-base. Maryam's research
[10] resulted in students' understanding of the concept of acid-base in submicroscopic aspects classified as low criteria, namely $48.1 \%$. In fact, in studying the topic of acidbase must be able to understand it fully, because acid-base material requires understanding connected to many chemical concepts that can be applied to subsequent materials, namely hydrolysis of salt and buffer solution. The development of instructional media in the form of learning materials has been carried out by other researchers, for example Sulistiawati. The study produced digital learning materials that were valid and suitable for use in the learning process. But apparently this digital learning material is not effectively used in the learning process proven by research Khoirun [8] and Nadhirotul [11] which states that there is no significant difference between students who are taught using digital learning materials with students who are taught without using digital learning materials. Nadhirotul [11] states that it happens because the learning material used lacks the interaction of the three representations.

Very rapid technological developments provide many alternatives for the development of instructional media that are able to explain chemistry in all three levels of representation, and can walk interactively so students are interested in the learning process, one of which is technology augmented reality. The purpose of augmented reality is the addition of understanding and information where the system augmented reality takes the real world as a basis and combines several technologies to improve one's 
understanding so that it looks as if virtual objects are in plain sight. The use of technology augmented reality has also been investigated by Pranata [13] which states that smartphone with the Android operating system so that students can access easily through the application, as well as being flexible, and easy to carry anywhere. Based on those basic problems, this research aims to develop guided inquiry-based learning material that enriched with augmented reality in acid-base material.

\section{METHOD}

The development of this learning material uses the multimedia-based development model Lee and Owens [9] which consists of the stages assessment /analysis, design, development, implementation, and evaluation. This research only carried out the third stage of development. Lee Owens's development model presented on Figure 1.

The phase assessment / analysis consists of two activities namely need assessment and front-end analysis. At the stage design, arranged storyboard is to determine what components will be included in the learning material. storyboard Thiswas then developed using several software such as Unity 3D, Blender, and Adobe After Effects. The results of this development stage are then reviewed and revised by the supervisor, then the final results are validated by one lecturer and one chemistry teacher. The instrument used in the form of an assessment questionnaire with a Likert scale of $1-5$ is equipped with a suggestion and

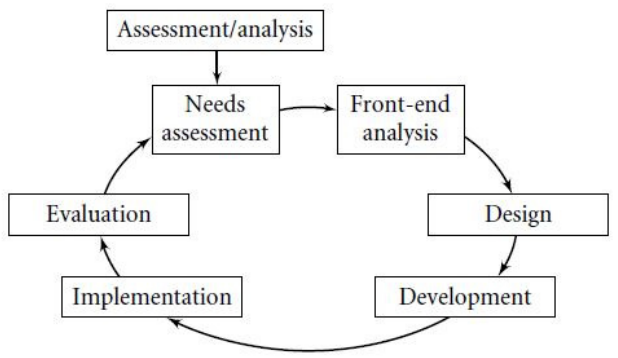

comment column. After giving suggestions and comments from the validator, the learning material was revised again and then readability tests were conducted on students. Figure 1 Lee Owens's Development Model

\section{RESULT AND DISCUSSION}

Learning materials developed in the form of books containing 2D or 3D learning animation videos with technology augmented reality, as well as Google forms can be used as student worksheets and students can access them through the qr code link on learning materials. This learning material consists of 4 sections, namely 1) characteristics and examples of acid base in everyday life, 2) Arrhenius acid base theory, 3) Bronsted-Lowry acid base theory, 4) Lewis acid-base theory. Each section has 7 levels, namely orientation, determining the formulation of the problem, determining the prediction of answers, collecting data, analyzing data, conclusions, and also self competency test. students are more enthusiastic, attentive, and play a more active role in the learning process that utilizes technology augmented reality. This technology can be presented in At the end of this learning material is also equipped with a final evaluation to measure students' understanding of acidbase material that is equipped with features students can see the score obtained and the answer key after working on the evaluation.

\subsection{Material Validation Results}

Table 1. Material Vaidation Results of All Aspect by Three Validators

\begin{tabular}{clcl}
\hline No & Rated Aspect & $\mathbf{P}(\boldsymbol{\%})$ & Criteria \\
\hline 1 & Material scope & 90 & Very feasible \\
2 & Material content & 86.3 & Very feasible \\
3 & Presentment & 90 & Very feasible \\
\hline 4 & Languange & 82.5 & Very feasible \\
\hline & Average & $\mathbf{8 6 . 7}$ & Very feasible \\
\hline
\end{tabular}

Based on the results that shown on Table 1, it can be concluded that this learning material is very feasible to use in learning acid-base material with a percentage of $86.7 \%$

\subsection{Media Validation Results}

Table 2 Media Vaidation Results of All Aspect by Three Validators

\begin{tabular}{clcc}
\hline No & Rated Aspect & $\mathbf{P}(\%)$ & Criteria \\
\hline 1 & $\begin{array}{l}\text { Graphics } \\
\text { The use of } \\
\text { animation and } \\
\text { augmented reality }\end{array}$ & 86.7 & Very feasible \\
\hline \multicolumn{1}{c}{ Average } & $\mathbf{8 2 . 7}$ & Fery feasible \\
\hline
\end{tabular}

Based on the results that shown on Table 2, it can be concluded that this learning material is very feasible to use in learning acid-base material with a percentage of $82.7 \%$

\subsection{Analysis of Student Readability Results}

After validation done by the expert, this learning material can be tested out its readability for 20 students in XI class SMAN 1 Malang. The readability test data obtained is presented in Table 3.

Table 3 Analyzes of Student Readability Results

\begin{tabular}{cccc}
\hline No & Rated Aspect & $\mathbf{P}(\%)$ & Criteria \\
\hline 1 & $\begin{array}{l}\text { Learning } \\
\text { Material } \\
2\end{array}$ & 91.7 & Very feasible \\
Rugmented & 93.3 & Very Feasible \\
\hline & Average & $\mathbf{9 2 . 1 7}$ & Very feasible \\
\hline
\end{tabular}

Based on the results of the validation it can be concluded that this learning material is very feasible to use in learning acid-base material with a percentage of $92.17 \%$ 
The advantages of learning material developed are loading learning videos in the form of $2 \mathrm{D}$ and $3 \mathrm{D}$ that can be easily accessed by students through smartphones so that they are real world as if they were in plain sight. This learning material is systematically arranged using the guided inquiry learning model so that it can be used as additional or alternative learning material that can be used independently by students.

The weakness of the learning material developed is that it requires internet access to be able to access learning content. In addition, the discussion of acid-base $\mathrm{pH}$ calculation cannot be studied more deeply through 3D learning videos with technology augmented reality. Development is limited to only the third stage. Therefore, it is necessary to conduct field trials to find out the effectiveness of learning materials whether it can improve student understanding and can facilitate teachers in explaining acid-base material.

\section{CONCLUSIONS}

The development carried out resulted in a guided inquirybased learning material product enriched with augmented reality on acid-base material with $86.7 \%$ validity for material validity and $82.7 \%$ for media validity, and $92.17 \%$ for the readability test on students with very criteria valid and feasible to be used as an alternative learning material in the process of learning chemistry in acid-base material. Learning materials consist of 4 sections, each of which has 7 stages of guided inquiry.

\section{REFERENCES}

[1] Arsyad, A. 2014. Media Pembelajaran. Jakarta : Rajawali Pers.

[2] Azuma, R.T. 2006. A Survey of Augmented Reality. Teleoperators and Virtual Environments 6(4), 355-385. DOI: 10.1162/pres.1997.6.4.355

[3] Berg, K.D. 2012. A Study of First Year Chemistry Students Understanding of Solution Concentration at The Tertiary Level. Chemistry Education Research and Practice. 13: 8-16.

[4] Chang, R. 2010. Chemistry $10^{\text {th }}$ edition. New York: The MC Graw-Hill Companies, Inc.

[5] Depdiknas. 2008. Panduan Pengembangan Bahan Ajar. Jakarta: Dinas Pendidikan Nasional.

[6] Effendy. 2010. A-Level Chemistry for Senior High School Students Volume 2A. Malang: Bayumedia Publishing

[7] Kemendikbud. 2016. Silabus Mata Pelajaran Sekolah Menengah Atas/Madrasah Aliyah (SMA/MA)

Mata Pelajaran Kimia. Jakarta: Kemendikbud

more flexible and can be used independently by students. This learning material is also equipped with technology augmented reality that can deliver virtual objects into the
[8] Khoirun, R. N. 2018. Efektivitas Penerapan Bahan Ajar Digital Berbasis Inkuiri Terbimbing Pada Materi Asam Basa Terhadap Hasil Belajar Kognitif Siswa Kelas XI MAN 1 Kota Malang. Malang: FMIPA UM.

[9] Lee, W.W., Owens, D.L. 2004. Multimedia Based Instructional Design Computer-Based Training WebBased Training Distance Broadcast Training Performance-Based Solution Second Edition. USA: Pfeiffer

[10] Mariyam, Siti. 2014. Tingkat Pemahaman Aspek Makroskopik, Mikroskopik, dan Simbolik Konsep Asam Basa Kelas XI SMKN 11 Malang. Skripsi tidak diterbitkan. Malang: FMIPA UM.

[11] Nadhirotul, U. L. 2018. Efektivitas Penggunaan Bahan Ajar Digital Berbasis Inkuiri Terbimbing Pada Materi Asam Basa Terhadap Hasil Belajar Kognitif Persepsi Siswa Kelas XI SMA Negeri 10 Malang. Skripsi tidak diterbitkan. Malang: FMIPA UM.

[12] Permendiknas No. 22 Tahun 2006 Tentang Standar Isi untuk Satuan Pendidikan Dasar dan Menengah. BSNP Indonedia. (Online), (http://bsnpindonesia.org), diakses 8 Januari 2019.

[13] Pranata, D. B. 2017. Pengembangan Bahan Ajar Cetak Berbasis Augmented Reality pada Mata Pelajaran IPA Untuk Siswa Kelas VII. Tesis tidak diterbitkan. Malang: Pascasarjana UM.

[14] Sadiman, A.S. 2010. Media Pendidikan : Pengertian, Pengembangan, dan Pemanfaatannya. Jakarta: PT. Rajagrafindo Persada

[15] Saidin, N.F., Halim, N.D.A., \& Yahayai, N. 2015. A Review of Research on Augmented Reality in Education Advantages and Applications. International Education Studies, 8 (13) : 1-8.

[16] Sheppard, K. 2006. High School Student Understanding of Titrations and Related Acid-Base Phenomena. Chemistry Education Research and Practice, 7 (1).

[17] Sudrajat, A. 2011. Pembelajaran Inkuiri. (Online), (http://akhmadsudrajat.wordpress.com/2011/ 09/12/pembelajaran-inkuiri/), diakses 12 Januari 2018

[18] Sulistiawati. 2017. Pengembangan bahan ajar digital berbasis inkuiri terbimbing pada materi asam basa untuk SMA/MA. Skripsi tidak diterbitkan. Malang: FMIPA UM.

[19] Taber, K.S. 2013. Revisiting the Chemistry Triplet: Drawing Upoon the Nature of Chemical Knowledge and the Psychology of Learning to Inform Chemistry Education. Chemistry Education Research and Practice, 14, 156-168 